\title{
The Nutritional Status of Filipino Pregnant Adolescents 14 to 19 Years Old in a Tertiary Hospital
}

\author{
Vanessa-Maria F. Torres-Ticzon, Emma Alesna-Llanto and Rosa Ma. H. Nancho \\ Division of Adolescent Medicine, Department of Pediatrics, College of Medicine and Philippine General Hospital, University of the Philippines Manila
}

\begin{abstract}
Objectives. 1) To determine the nutritional status of pregnant adolescents aged 14 to 19 years seen at the Philippine General Hospital Teen Mom Clinic from February to July 2014; 2) To describe the demographic characteristics, pregnancy history, and lifestyle and health habits of adolescent mothers; 3 ) To describe the adequacy of the daily intake of nutrients (caloric energy, carbohydrates, protein, fats, folate, calcium, and iron) of adolescent mothers; and 4) To determine the association of specific demographic characteristics with body mass index categories.

Methods. This was a prospective cross-sectional study. Included were the pregnant adolescents aged 14 to 19 years of age, referred to the Teen Mom Clinic, who planned to deliver at the Philippine General Hospital. Informed consent and assent forms were signed, and the principal investigator interviewed the subjects for demographic and clinical history at the time of enrolment. The adolescents were taught and instructed to fill up the food diary ( 2 weekdays and 1 weekend) and the food frequency (once) forms. These were submitted on their next visit and given to a licensed nutritionist for analysis. The nutritional status was assessed by gathering the weight and height of the patients in order to compute for the body mass index at the time of enrolment in the study.
\end{abstract}

Results. The percentage distribution of nutritional status of pregnant adolescents consisted of the following: $65 \%$ normal; $28 \%$ underweight; $3.5 \%$ overweight; $3.5 \%$ obese. The 60 pregnant adolescents had a mean age of 16.9 years (SD 1.2). Their partners had a mean age of 20.3 years [SD 3.8]. On the average, they had a total of five pre-natal checkups. Majority of the respondents (85\%) still depended primarily on their parents for financial support. Around $93 \%$ of the pregnancies were unplanned. Their median percent adequacy for daily calories was $72 \%$, carbohydrates $69 \%$, proteins $73 \%$, and fats $86 \%$. For the micronutrients, the median percent adequacies for folate, calcium, and iron, based on the needs of pregnant women, were $18 \%, 63 \%$, and $29 \%$, respectively. If amounts were compared to the requirements by age, the median adequacies of intake were $27 \%, 50 \%$, and $41 \%$, respectively. The nutritional status was not found dependent on the age, educational attainment, number of siblings, and the monthly family income of the respondents.

Conclusion. Only $65 \%$ of the pregnant adolescents had normal nutritional status. There was still an elevated level of malnutrition among pregnant adolescents as shown in this study: $28 \%$ were underweight, $3.3 \%$ were overweight, and another $3.3 \%$ were obese.

Key Words: pregnant adolescent, teen mom, maternal nutrition

\section{INTRODUCTION}

At present, teenage pregnancy is considered as a public

Paper presented at the Society of Adolescent Medicine of the Philippines, Inc. (SAMPI) Biennial Convention, September 28-29, 2016, Marco Polo Ortigas Manila.

Corresponding author: Vanessa Maria F. Torres-Ticzon, MD Department of Pediatrics

Philippine General Hospital

University of the Philippines Manila

Taft Avenue, Manila 1000, Philippines

Email:vmftorresc@gmail.com health burden, more than just a personal and family problem. It is defined as becoming pregnant below 20 years of age. The Lancet in 2016 stated that the youth at 10 to 24 years is estimated to be at around 1.8 billion people; they represent around a fourth of the world's population. ${ }^{1}$ These young women are becoming pregnant and yet are still undergoing a lot of physical, cognitive, and psychosocial changes in their body. Hence, they carry a great responsibility of taking care of another human being while they themselves are still maturing. 
One of the common areas of concern regarding teenage mothers is their poor nutritional intake due to the limited awareness in proper nutrition, unavailability of resources to provide for their basic needs, lack of proper guidance and support from their homes, and their desire to explore as well as fulfill their curiosity.

Essential to childbearing is the good nutritional status of the mothers in order to support the increasing needs of the fetus. This study aimed to determine the actual dietary intake and nutritional status of adolescent Filipino mothers aged 14 to 19 years. This will serve as the basis of recommendations for nutritional intervention among pregnant adolescents which may later on help alter the negative outcomes in both mothers and infants, thus, improving maternal health and decreasing child mortality which are the Millennium Development Goals four and five, respectively. This study is crucial since it will set the baseline dietary intake and nutritional status of Filipino adolescent mothers in a tertiary hospital setting through the use of food diary and food frequency forms.

\section{OBJECTIVES}

The objectives of the study were as follows:

1. To determine the nutritional status of pregnant adolescents aged 14 to 19 years seen at the Philippine General Hospital Teen Mom Clinic from February to July 2014

2. To describe the demographic characteristics, pregnancy history, and lifestyle and health habits of adolescent mothers

3. To describe the adequacy of the daily intake of nutrients (caloric energy, carbohydrates, protein, fats, folate, calcium, and iron) of adolescent mothers

4. To determine the association of specific demographic characteristics with BMI categories

\section{Significance}

Detailed history taking of diet during pregnancy is not usually feasible due to time constraints in the clinic. However, it is known that poor nutritional status in the antenatal period increases risk for adverse neonatal outcomes. A baseline knowledge of the typical nutritional profile and eating habits of pregnant adolescents seen at the Teen Mom Clinic may help clinicians better manage this special subset of would-be mothers and possibly highlight the need for implementing additional measures so as to enhance chances for a good pregnancy outcome.

\section{Review of related literature}

The adolescent birth rate is at 53 births per 1,000 girls aged $15-19$ as of $2010 .^{2}$ According to the 2008 results of the National Nutrition Survey by the Food and Nutrition Research Institute, it was shown that 26.3 percent, or one in every four Filipino pregnant women is nutritionally-atrisk. Pregnant women who were below the 95th percentile based on weigh-for-height cut-off points are considered nutritionally-at-risk. The proportion of nutritionally-at-risk pregnant women significantly decreased by 2.1 percentage points, from 2005 with a 28.4 percent prevalence rate, to 26.3 percent in $2008 .^{3}$

Improvement in maternal health is the fifth among the Millennium Development Goals which the Philippines has endeavored to achieve. Pregnant women have high nutritional needs. A pregnant woman not only has to satisfy her own nutritional requirements but also that of the growing fetus. Her nutritional status before and during pregnancy plays a major role in determining the nutritional status of her infant.

Poor nutrition among pregnant women results to low birth weight babies, and they may experience difficult labor and complications such as hemorrhage, infection, and high blood pressure, among others. The National Nutrition Survey showed that 43 in every 100 pregnant women are anemic. ${ }^{3}$ Prevalence of anemia among pregnant women is still of high public health concern, as well as the other energy and nutrient deficiencies.

A food pyramid for pregnant women (Appendix A) ${ }^{4}$ and standards for total and rate of weight gain during pregnancy (Appendix B) ${ }^{5}$ have been recommended. Body mass index (BMI) guidelines recommended by the World Health Organization to be followed are independent of age, parity, smoking, history, race, and ethnic background.

A food diary or food record is a method wherein individuals are asked to write down all the foods and beverages consumed over a specific period, ${ }^{6}$ usually one, three, or seven days. It must be emphasized that eating practices must not change during record keeping. This method is valuable for counseling of nutritional problems. According to the Nutritionist-Dietitians Association of the Philippines Diet Manual $5^{\text {th }}$ edition, a three-day food record taken on midweek days may be enough to determine the average nutrient and food intake especially if there is accurate recording (Appendix C). ${ }^{7}$ The Seventh National Nutrition Survey released a list of foods frequently consumed by pregnant women (Appendix D). ${ }^{3}$

The advantages of using a food diary include the following: (a) it does not rely on memory, (b) food may be measured at the time of consumption, and (c) recording for several days provides a valid measure of intake and meal patterning. However, limitations are as follows: (a) it may influence the food intake due to its recording, (b) it requires some level of literacy, (c) it relies on self-reported information, (d) it requires a skilled staff, and (e) it may be time consuming. A food diary is helpful for the assessment of intake of a variety of nutrients and is likewise a useful counseling tool.

In contrast to a food diary, wherein the patients themselves fill up the form, a nutritionist interviews and records the answers of the patients in a 24-hour food recall. On the other hand, a food frequency questionnaire (Appendix E) ${ }^{7}$ is a method that involves asking patients how often they eat the foods on a list over a specified period. It helps to evaluate 
the main diet and to determine later on what modifications are needed. It is helpful when used in combination with a food record or a 24-hour recall. It has two main parts, namely: the list of food and the columns indicating the frequency of use over a certain time duration. It is usually a part of the diet history.

The advantages of a food frequency questionnaire are as follows: (a) it is fast to use, easy, and affordable; (b) it may assess the current as well as past diet; and (c) it may be used as a screening tool. Limitations include the following: (a) it does not give valid estimates of the absolute intake of individuals, (b) it cannot assess meal patterning, and (c) it may not be appropriate for some groups. A food frequency questionnaire has limited usefulness in clinical settings, and may be used more as a screening tool.

According to Natividad, women at age 15 and below are at increased risk for maternal death, early neonatal death, and anemia compared with those in the older age groups. Those belonging to less than twenty years also have a higher risk for postpartum hemorrhage, low birth weight, preterm delivery, and to have small for gestational age infants. ${ }^{8}$

Aside from the health risks, teenage pregnancy also leads to other problems such as being unable to finish schooling which prevents the adolescent mother from maximizing her potentials, exposing herself to social stigma, and having higher risks to future pregnancies. Based on studies, adolescent mothers had the shortest birth intervals at approximately 20 months, as compared to the older age groups who have a usual interval of 30 to 34 months. $^{8}$

There is a decline in the total fertility rate of the Philippines: from six children in 1973 to 3.3 in 2008. The total fertility rate is the expected number of children a woman who survives to the end of the reproductive age span will have during her lifetime. Still, the fertility rate of the fifteen to nineteen age group has remained constant, from 56 births per thousand women in 1973 to 54 per thousand in $2008 .^{8}$

There are three factors that have been shown to lead to increased prevalence of teenage pregnancy, namely: living in the rural areas, women with low educational attainment, and the poor. At present, the trends are changing. There is an increasing proportion of women in the urban areas, who are better educated, and who come from the middle to the upper socioeconomic status who have started childbearing in their teens. These findings have been associated with early marriage, but more importantly, to premarital sexual activity. Another contributory factor is the decreasing age at menarche nowadays, from an average of fifteen to twelve years. Still another important variable is the increasing acceptance of premarital sex in society. ${ }^{8}$

\section{METHODS}

\section{Design and setting}

This was a prospective cross-sectional study conducted at the PGH Teen Mom Clinic from February to July 2014.
The Philippine General Hospital is a government tertiary referral center catering mostly to patients of lower socioeconomic status. Its major catchment areas are Manila and the nearby Southern Tagalog municipalities. The said clinic is the referral site for high-risk teen pregnancies seen at the UP-PGH Out-Patient Department, and it offers individualized counselling to its clients during the prenatal checkups as well as at postpartum. Participants were recruited during one of their prenatal visits.

After obtaining the informed consent, and assent for those below the legal age of 18 years, the BMI was computed by dividing weight in kilograms by the square of the height in meters. The BMI categories (normal/ underweight/ overweight/ obese) were based on definitions of the current World Health Organization International BMI Classification for Adults (Appendix B). ${ }^{5}$ They were referred to the Dietary Department where they were taught how to fill up the food diary and food frequency forms, in Filipino language, that were based on the Nutritionist-Dietitians Association of the Philippines Diet Manual, $5^{\text {th }}$ edition. $^{7}$ The food diary was done for three days: two weekdays and a weekend. The food frequency form was accomplished once. The subjects submitted their accomplished forms to the primary investigator at their next visit with the Section of Perinatology, about two to four weeks after, depending on the age of gestation of these teen mothers. Responses to the food diary and food frequency forms were analyzed by a licensed nutritionist for nutritional content and compared against the Department of Science and Technology Food and Nutrition Research Institute (DOST-FNRI) recommended daily allowance of nutrients for pregnant adolescents (Appendix F) ${ }^{7}$ to determine adequacy of intake. Adequacy of folic acid, calcium and iron were computed based on needs for age as well as on needs of pregnant women.

\section{Study criteria}

Enrolled in this study were the pregnant adolescents aged 14 to 19 years who consulted at the Outpatient Department of the Philippine General Hospital (PGH) and who planned to deliver in the same institution. They were referred from the Adolescent Clinic of the Department of Pediatrics, or from the Department of Obstetrics and Gynecology. Excluded were pregnant teenagers with chronic medical conditions (e.g. tuberculosis, diabetes, rheumatic heart disease) since there is high probability that their nutritional status is affected by their chronic illness. Also excluded are those with psychiatric illness, cognitive disability, and those who did not consent to join the study.

\section{Assessments}

The BMI was determined by dividing the weight in kilograms by the square of the height in meters. The demographic data was taken particularly the age of the respondents and their educational attainment, number of pregnancies, number of siblings, birth order of the respondent, 
age and educational attainment of the partner, primary source of financial support, monthly family income, living arrangement, age of gestation upon knowing of the pregnancy, age of gestation of the first prenatal checkup, if the pregnancy was planned or not, use of a family planning method, use of alcohol/tobacco/drugs, and intake of supplements. The pregnant adolescents were asked to fill up the food diary and food frequency forms which became the basis of the record for nutrient intake.

\section{Sample size computation}

The Teen Mom Clinic census for 2012 indicated a total of 125 patients for the whole year. As the recruitment phase of the study was planned to run for six months, about 62 available samples were expected. A minimum number of 55 required subjects was computed based on a $53.9 \%$ prevalence of normal BMI among pregnant adolescents, ${ }^{9}$ confidence and precision levels of $95 \%$ and $5 \%$, respectively, and after correcting for finite sample. The formula used for calculating sample size was that of Daniel (1999). ${ }^{10}$

$$
\mathrm{n} \geq \frac{\mathrm{z}_{a / 2}{ }^{2} \times P \times(1-P)}{\mathrm{d}^{2}} \quad \mathrm{n} \geq \frac{1.96^{2} \times P \times(1-P)}{.05^{2}}
$$

The computed sample size was corrected for finite population using the following formula to derive the adjusted sample size:

$$
\mathrm{N}_{\text {adjusted }}=\frac{\text { Computed Sample }}{1+\frac{\text { Computed Sample }-1}{\text { Population }}}
$$

The sample size estimate was taken to be the largest computed, which was 55 subjects.

\section{Statistical analysis}

The demographic data, clinical and personal history, and nutrient intake and adequacy were summarized using simple descriptive statistics (mean with standard deviation or median with range for quantitative data, count with percentage for categorical data). The association of specific demographic characteristics with BMI categories was analyzed by two-tailed Fisher's exact test. Significance was set at alpha level of $<5 \%$.

\section{Ethical considerations}

This study complies with the ethical principles contained in the 2013 Declaration of Helsinki and the 2011 National Ethical Guidelines for Health and Health Related Research of the Philippine Health Research Ethics Board. All study data were anonymized to maintain the privacy of the participants. No patient was coerced into joining the study. Informed consent and assent forms, as applicable, were documented in writing for all participants after adequately explaining to them the study goals and methods. Respondents were allowed to withdraw from the study at any time they wished to without fear of any repercussion.

\section{RESULTS}

\section{Nutritional status}

Table 1 shows the BMI category of the respondents: $65 \%$ were normal while $28 \%$ were underweight. There were $3.3 \%$ who were overweight and another $3.3 \%$ who were obese. Table 2 shows the association of demographic characteristics with the BMI category of the pregnant adolescents. There was insufficient evidence to support a significant association of BMI class with age, educational attainment, number of siblings, and monthly family income of respondents.

Table 1. BMI category upon study enrolment of respondents $(n=60)$

\begin{tabular}{lc}
\hline & Count (\%) \\
Underweight $\left(<18.5 \mathrm{~kg} / \mathrm{m}^{2}\right)$ & $17(28.3)$ \\
Normal $\left(18.5-24.9 \mathrm{~kg} / \mathrm{m}^{2}\right)$ & $39(65)$ \\
Overweight $\left(25.0-29.9 \mathrm{~kg} / \mathrm{m}^{2}\right)$ & $2(3.3)$ \\
Obese $\left(\geq 30 \mathrm{~kg} / \mathrm{m}^{2}\right)$ & $2(3.3)$ \\
\hline
\end{tabular}

\begin{tabular}{|c|c|c|c|c|c|}
\hline & Underweight $(n=17)$ & Normal $(n=39)$ & Overweight $(n=2)$ & Obese $(n=2)$ & p-value \\
\hline 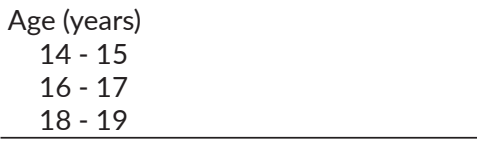 & $\begin{array}{c}0 \\
10(58.8) \\
7(41.2) \\
\end{array}$ & $\begin{array}{c}7(17.9) \\
18(46.2) \\
14(35.9)\end{array}$ & $\begin{array}{c}0 \\
0 \\
2(100) \\
\end{array}$ & $\begin{array}{c}0 \\
2(100) \\
0 \\
\end{array}$ & 0.181 \\
\hline $\begin{array}{l}\text { Educational attainment, } \mathrm{n}=59 \\
\text { Elementary school (under-)graduate } \\
\text { Secondary school (under-)graduate } \\
\text { College undergraduate/vocational }\end{array}$ & $\begin{array}{l}2(11.8) \\
7(41.2) \\
8(47.1) \\
\end{array}$ & $\begin{array}{c}1(2.6) \\
24(63.2) \\
13(34.2)\end{array}$ & $\begin{array}{c}0 \\
1(50) \\
1(50) \\
\end{array}$ & $\begin{array}{c}0 \\
1(50) \\
1(50) \\
\end{array}$ & 0.500 \\
\hline $\begin{array}{l}\text { Monthly family income (Php) } \\
\quad<5,000 \\
5,000-1,0000 \\
10,000-15,000 \\
>15,000\end{array}$ & $\begin{array}{l}6(35.3) \\
8(47.1) \\
1(5.9) \\
2(11.8) \\
\end{array}$ & $\begin{array}{l}14(35.9) \\
5(12.8) \\
9(23.1) \\
11(28.2)\end{array}$ & $\begin{array}{c}1(50) \\
1(50) \\
0 \\
0 \\
\end{array}$ & $\begin{array}{c}0 \\
1(50) \\
0 \\
1(50)\end{array}$ & 0.066 \\
\hline $\begin{array}{l}\text { Number of siblings } \\
\begin{array}{l}0-2 \\
3-5 \\
6-9\end{array}\end{array}$ & $\begin{array}{c}5(29.4) \\
11(64.7) \\
1(5.9) \\
\end{array}$ & $\begin{array}{c}21(53.8) \\
15(38.5) \\
3(7.7) \\
\end{array}$ & $\begin{array}{c}1(50) \\
1(50) \\
0 \\
\end{array}$ & $\begin{array}{c}2(100) \\
0 \\
0 \\
\end{array}$ & 0.378 \\
\hline
\end{tabular}

Table 2. Association of demographic characteristics with BMI category of respondents $(n=60)$ 
Table 3. Demographic and pregnancy profile of respondents $(n=60)$

\begin{tabular}{|c|c|}
\hline & $\begin{array}{l}\text { Mean } \pm \text { SD or } \\
\text { Median (Range); } \\
\text { Count (\%) }\end{array}$ \\
\hline $\begin{array}{l}\text { Demographic characteristics } \\
\text { Age (years) } \\
14-15 \\
16-17 \\
18-19\end{array}$ & $\begin{array}{l}16.9 \pm 1.2 \\
7(11.7) \\
30(50) \\
23(38.3)\end{array}$ \\
\hline $\begin{array}{l}\text { Educational attainment, } \mathrm{n}=59 \\
\text { Elementary school (under-)graduate } \\
\text { Secondary school (under-)graduate } \\
\text { College undergraduate/vocational }\end{array}$ & $\begin{array}{c}3(5.1) \\
33(55.9) \\
23(39)\end{array}$ \\
\hline $\begin{array}{l}\text { Monthly family income (Php) } \\
\quad<5,000 \\
5,000-10,000 \\
10,000-15,000 \\
\quad>15,000\end{array}$ & $\begin{array}{c}21(35) \\
15(25) \\
10(16.7) \\
14(23.3)\end{array}$ \\
\hline $\begin{array}{l}\text { Number of siblings } \\
\begin{array}{l}0-2 \\
3-5 \\
6-9\end{array}\end{array}$ & $\begin{array}{l}2.9 \pm 1.8 \\
29(48.3) \\
27(45) \\
4(6.7)\end{array}$ \\
\hline $\begin{array}{l}\text { Birth order } \\
1^{\text {st }} \\
2^{\text {nd }} \\
3^{\text {rd }}-6^{\text {th }}\end{array}$ & $\begin{array}{l}30(50) \\
12(20) \\
18(30)\end{array}$ \\
\hline $\begin{array}{l}\text { Living arrangement, } \mathrm{n}=57 \\
\text { With parents } \\
\text { With partner's family } \\
\text { With partner only } \\
\text { Others }\end{array}$ & $\begin{array}{l}37(64.9) \\
12(21) \\
3(5.3) \\
5(8.8)\end{array}$ \\
\hline $\begin{array}{l}\text { Primary source of financial support, } \mathrm{n}=4 \\
\text { Parents } \\
\text { Partner } \\
\text { Others }\end{array}$ & $\begin{array}{c}40(85.1) \\
3(6.4) \\
4(8.5)\end{array}$ \\
\hline $\begin{array}{l}\text { Partner } \\
\text { Age (years) } \\
\text { Working, } n=57\end{array}$ & $\begin{array}{l}20.3 \pm 3.8 \\
36(63.2)\end{array}$ \\
\hline $\begin{array}{l}\text { Pregnancy history } \\
\text { No. of previous pregnancies }\end{array}$ & $0(0-3)$ \\
\hline $\begin{array}{l}\text { Current pregnancy } \\
\text { Unplanned } \\
\text { AOG at discovery (months), } \mathrm{n}=59 \\
\text { AOG at initial Teen Mom Clinic visit } \\
\text { (months), } \mathrm{n}=59\end{array}$ & $\begin{array}{l}56(93.3) \\
2.3 \pm 1.0 \\
3.6 \pm 1.4\end{array}$ \\
\hline
\end{tabular}

\section{Demographic data}

A total of 60 pregnant adolescents aged 14 to 19 years were recruited and gave consent to join this study. As seen in Table 3, their mean age was 16.9 years old (SD 1.2). On the other hand, their partners had an age range of 16 to 35 years, with a mean of 20.3 years (SD 3.8). Around $61 \%$ of the respondents had obtained at most a high school diploma, while $34 \%$ reached college level. The primary source of financial support was their parents. Majority had a monthly family income of Php 1,000 - Php 5,000.

Majority of the adolescent mothers were pregnant for the first time. Around 93\% of the pregnancies were unplanned. Of all the pregnancies, around 91\% did not use any family planning method. The patients mostly learned
Table 4. Lifestyle and health habits of respondents $(n=60)$

\begin{tabular}{lc} 
& Count (\%) \\
Smoking in past year & $11(18.3)$ \\
Alcohol drinking in past year & $19(32.2)$ \\
Illicit drug use, $\mathrm{n}=59$ & 0 \\
Food supplement intake & \\
$\quad$ Multivitamins & $54(90)$ \\
Ferrous sulfate & $55(91.7)$ \\
Folic acid & $10(16.7)$ \\
None & $2(3.3)$ \\
\hline
\end{tabular}

Table 5. Typical diet composition of respondents

$\begin{aligned} & \text { Top } 20 \text { foods consumed by pregnant adolescents seen at PGH } \\
& \text { Teen Mom Clinic, } 2013\end{aligned}$
\begin{tabular}{lll} 
1. Rice & 11. Pork \\
2. Milk & 12. Juice \\
3. Bread & 13. Other vegetables (e.g. squash) \\
4. Banana & 14. Other fruits (e.g. apple) \\
5. Sugar & 15. Beef \\
6. Green, leafy vegetables & 16. Cooking oil \\
7. Egg & 17. Soft drinks \\
8. Chicken & 18. Potato or kamote (sweet potato) \\
9. Candy or chocolate & 19. Instant noodles \\
10. Fish and other seafoods & 20. Ice cream \\
\hline
\end{tabular}

Table 6. Percent adequacy of daily nutrient intake of respondents $(n=60)$

\begin{tabular}{lc} 
& Mean \pm SD \\
Calories & $76.7 \pm 19.0$ \\
Carbohydrates & $70.4 \pm 18.8$ \\
Protein & $77.9 \pm 20.8$ \\
Fat & $90.9 \pm 29.9$ \\
Folate (pregnant) & $19.1 \pm 7.7$ \\
Calcium (pregnant) & $66.9 \pm 25.9$ \\
Iron (pregnant) & $33.9 \pm 16$ \\
Folate (age) & $28.7 \pm 11.6$ \\
Calcium (age) & $54.0 \pm 22.2$ \\
Iron (age) & $46.3 \pm 19.6$ \\
\hline
\end{tabular}

about their pregnancy at two months age of gestation, but they generally delayed going for an initial prenatal checkup until the second trimester.

Table 4 describes the lifestyle and health habits of the respondents. Within the past year, $18 \%$ of the respondents were smoking while $32 \%$ took alcohol. Most of the respondents took at least multivitamins and ferrous sulfate as food supplements.

\section{Nutritional intake}

The typical diet composition of adolescent mothers consisted of rice, milk, bread, banana, sugar, green leafy vegetables, egg, chicken, candy or chocolate, and fish and other seafood (Table 5). The median percent adequacy for daily calories was $72 \%$, with $69 \%$ for carbohydrates, $73 \%$ for proteins, and $86 \%$ for fats (Table 6). These meant that the respondents were mostly getting less than the recommended amount of these macronutrients daily. For the micronutrients, it could be noted that the median percent adequacies for folate, calcium, and iron, based on the needs of pregnant women, were $18 \%, 63 \%$, and $29 \%$, respectively. 
If amounts were compared to the requirements by age, the median adequacies of intake were $27 \%, 50 \%$, and $41 \%$, respectively. Thus, regular intake of micronutrients was found inadequate for majority of the teenage mothers especially for folate and iron.

\section{Association of demographic characteristics with BMI}

Among the various sociodemographic data such as the age of the respondents, their educational attainment, their family size, and their monthly family income, only the income of the family turned out to be statistically correlated with the nutritional status of the teenage mothers.

\section{DISCUSSION}

The trend of teenage pregnancy has been changing through the years. Previously, this phenomenon was commonly seen in rural areas, among the poor, and those having a low educational attainment. In contrast to this, Natividad pointed out an increasing trend of adolescent pregnancy among those who are not poor, who have a higher educational attainment, and those who reside in urban areas. ${ }^{8}$

In the study of dela Cruz, it was mentioned that poverty leads to maternal malnutrition which is implicated in complications such as premature labor, low birth weight in their neonates, among others. These adolescents have nutrients that have been depleted due to their poor diet, increase in demands for their own growth and development as well as the needs of their offsprings. ${ }^{11}$ Garcia, in an earlier study, found the following factors to significantly affect teenage pregnancy: having a live-in partner, unemployed parents, being an out of school youth, family income less than Php 10,000, separated parents, having an older sexual partner, use of condom as a contraceptive method, and having televised media as a source of sex education. ${ }^{12}$

This current research is a baseline study of the nutritional status of Filipino pregnant adolescents in a tertiary hospital setting through the use of food diary and food frequency forms. In this study, the population came from a government tertiary hospital; most of them had a monthly income of less than Php 5,000. The various demographic characteristics that were correlated with the nutritional status were the age of the respondents, their educational attainment, the family size, and their monthly family income. There was no significant level of association between nutritional status and factors of age, educational attainment, monthly family income, and number of siblings.

Based on the study by Desnacido et al, data from a series of national nutrition surveys revealed a high prevalence of iron, vitamin A, folate, zinc, and riboflavin and other deficiencies. Multiple micronutrient deficiencies were quite common among pregnant women since only $19 \%$ of them had no deficiency in any of the aforementioned nutrients. ${ }^{13}$
Quite a high number of the teenage mothers were underweight in this study at $28 \%$. On the other hand, 3.3\% were overweight while another $3.3 \%$ were obese. According to the Eighth National Nutrition Survey in the Philippines ${ }^{14}$ conducted in 2013 to 2014, there was a prevalence of $12.4 \%$ of wasting and $31.5 \%$ of stunting among adolescents 10 to 19 years old. In the other end of the spectrum, there was a prevalence of $8.3 \%$ of overweight adolescents in the 22 million teenagers in the country. There are no available Philippine data focusing on the nutrition of pregnant adolescents alone.

Based on the analysis of the nutritional intake done using the food diary and food frequency, the presence of micronutrient deficiency is especially highlighted in this study particularly folate, iron, and calcium. Hence, it is quite important to emphasize repeatedly the value of proper diet especially foods rich in these micronutrients.

Examples of food sources rich in folate are green leafy vegetables like lettuce and spinach, citrus fruits like orange, papaya, beans and peas like garbanzos, avocado, okra, broccoli, asparagus, seeds like sesame and peanuts, cauliflower, corn, celery, carrots, and squash. Foods rich in iron include beef, chicken, crab, clams, egg yolk, fish, liver, pork, sardines, oysters, dried fruits like raisins, oranges, peas, soybeans, broccoli, watermelon, and peanuts. Those that are good sources of calcium are milk, shrimp, crab, cheese, yoghurt, sardines, green leafy vegetables, soybeans, tofu, salmon, okra, broccoli, sesame seeds, and peas.

Having proper diet by intake of healthy, nutritious as well as affordable foods must be communicated to these pregnant adolescents as well as to their family members. In this way, pregnancy and neonatal complications may be prevented. Of course, having early and regular prenatal checkups cannot be overemphasized. According to the study of Bullecer, et al., having a variety of foods is recommended since it ensures adequate intake of essential nutrients that promote good health. ${ }^{15}$

Nutrition is often overlooked, and this change needs to be addressed to ensure the good pregnancy and neonatal outcomes for the adolescent mothers and their babies, respectively. Aside from the adolescents who are still developing, their infants are also in much need of essential nutrients to likewise support their crucial growth and development. Educating the pregnant adolescents and the family members in charge of food preparation at home regarding the recommended diet for pregnant women such as the food pyramid guide from the Food and Nutrition Research Institute ${ }^{4}$ (Appendix A) is one concrete way of enabling them to understand and hopefully have healthier food choices.

\section{CONCLUSION}

There is still an elevated level of malnutrition among pregnant adolescents as shown in this study: $65 \%$ had normal BMI, while $28 \%$ were underweight, $3.3 \%$ were overweight, and another $3.3 \%$ were obese. 
The pregnant adolescents in this study had a mean age of 16.9 years old (SD 1.2). This was mostly their first pregnancy, and was unplanned. Their median percent adequacy for daily calories was $72 \%$, with $69 \%$ for carbohydrates, $73 \%$ for proteins, and $86 \%$ for fats. For the micronutrients, the median percent adequacies for folate, calcium, and iron, based on the needs of pregnant women, were $18 \%, 63 \%$, and $29 \%$, respectively. If amounts were compared to the requirements by age, the median adequacies of intake were 27\%, 50\%, and $41 \%$, respectively. The nutritional status was not found dependent on the age, educational attainment, number of siblings, and the monthly family income of the respondents.

\section{Recommendation}

It is recommended that a longer duration of time of the study be done so as to be able to recruit more participants. In later researches, the maternal outcomes of pregnancy as well as the neonatal outcomes may be gathered and correlated with the baseline BMI at the time of enrolment in the study. The expected weight gain per trimester may also be monitored in order to ensure proper nutrition of the pregnant adolescents. If not met, referral to the Dietary Service should be done so that these adolescents as well as their parents who may be the gatekeepers of food preparation at home may be properly educated on the recommended food choices.

\section{Acknowledgments}

The principal investigator is very much indebted to her supportive family - her loving and understanding husband Christian Melvin and of course, her loving, beautiful and smart children Noelle Margaret, Frances Miguela and Joseph Melvin, her sources of happiness and inspiration. She is forever indebted to her ever loving and supportive parents, Joel and Marivic as well as her sister Marjorel and her family. She is grateful to her statistician Jovel Nabia and her dear researcher friend, Krizchelle Chingsai as well as to Dr. Jossie Rogacion, her technical adviser. She is likewise grateful to the study respondents.

Most of all, she gives her endless praise and thanks to the One Who made all these possible, to her eternal and all-powerful GOD to Whom she surrenders everything.

\section{Statement of Authorship}

All the authors conceptualized the topic of this research paper. VMFTT wrote the research protocol, performed the data collection and analysis, and wrote the research manuscript. RMHN and EAL reviewed the research protocol and gave their inputs as content advisers. All the authors read and approved the final manuscript.

\section{Author Disclosure}

All authors declared no conflicts of interest.

\section{Funding Source}

This paper was funded by the primary author.

\section{REFERENCES}

1. Patton GC, Sawyer SM, Santelli JS, Ross DA, Rima Afifi R, Allen NB, et al. Our Future: a Lancet Commission on Adolescent Health and Well-Being. Lancet. 2016; 387(10036):2423-78.

2. UNICEF adolescent health [Internet]. [cited $2014 \mathrm{Feb}$ ]. Available from: https://www.unicef.org/health/index_92029.html.

3. Seventh National Nutrition Survey's Biochemical Survey Component by the Food and Nutrition Research Institute [Internet]. 2008 [cited $2014 \mathrm{Feb}$. Available from: http://www.ndap.org.ph/files/upload/7thNational\%20Nutrition\%20Survey.pdf

4. Food and Nutrition Research Institute website [Internet]. [cited 2014 Feb]. Available from: http://www.fnri.dost.gov.ph/index.php/toolsand-standard/nutritional-guide-pyramid\#pregnant.

5. Rasmussen K, Yaktine AL. Weight gain during pregnancy: reexamining the guidelines. USA: The National Academies Press, Committee to Reexamine IOM Pregnancy Weight Guidelines, Food and Nutrition Board, Board on Children, Youth, and Families; 2009. pp. 7-12.

6. Story M, Stang J. Nutrition and the pregnant adolescent a practical reference guide. USA: Center for Leadership, Education, and Training Maternal and Child Nutrition; 2000. pp. 37-46.

7. Nutritionist-Dietitians' Association of the Philippines. Diet Manual. 5th ed. Manila: Nutritionist-Dietitians' Association of the Philippines; 2010.

8. Natividad J. Teenage pregnancy in the Philippines: trends, correlates and data sources. JAFES. 2013; 28(1):30-7.

9. Vivatkusol Y, Thavaramara T, Phaloprakarn C. Inappropriate gestational weight gain among teenage pregnancies: prevalence and pregnancy outcomes. Int J Womens Health. 2017; 9:347-52.

10. Daniel WW, ed. Biostatistics: a foundation for analysis in the health sciences. 7th ed. New York: John Wiley \& Sons; 1999.

11. dela Cruz AC. Experience with teenage pregnancy at Eulogio Rodriguez, Sr. Memorial Hospital. The Journal of the Philippine Medical Association. 1996; 71(3):255-9.

12. Garcia JB. Factors affecting teenage pregnancy among Filipino adolescents in selected urban and rural institutions: a case control study. The Filipino Family Physician. 2005; 43(3):98-102.

13. Desnacido JA, Cheong RL, Perlas LA, Marcos JM, Madriaga JR. Prevalence and correlates of multiple micronutrient deficiencies among Filipino pregnant women. Philipp J Nutr. 2006; 53(3-4):13-24.

14. Eighth National Nutrition Survey. Food and Nutrition Research Institute, Department of Science and Technology, 2015.

15. Bullecer ER, Rabuco LB, Aninao DAB, De Roxas RC, Esguerra JCA, Lim PRU, et al. Dietary diversity score as an indicator of nutritional adequacy of diets among 16 to 19 year old adolescents. Acta Med Philipp. 2012; 46(1):28-33. 


\section{APPENDICES}

Appendix A. Recommended Food Pyramid for Pregnant Women from the Food and Nutrition Research Institute ${ }^{4}$

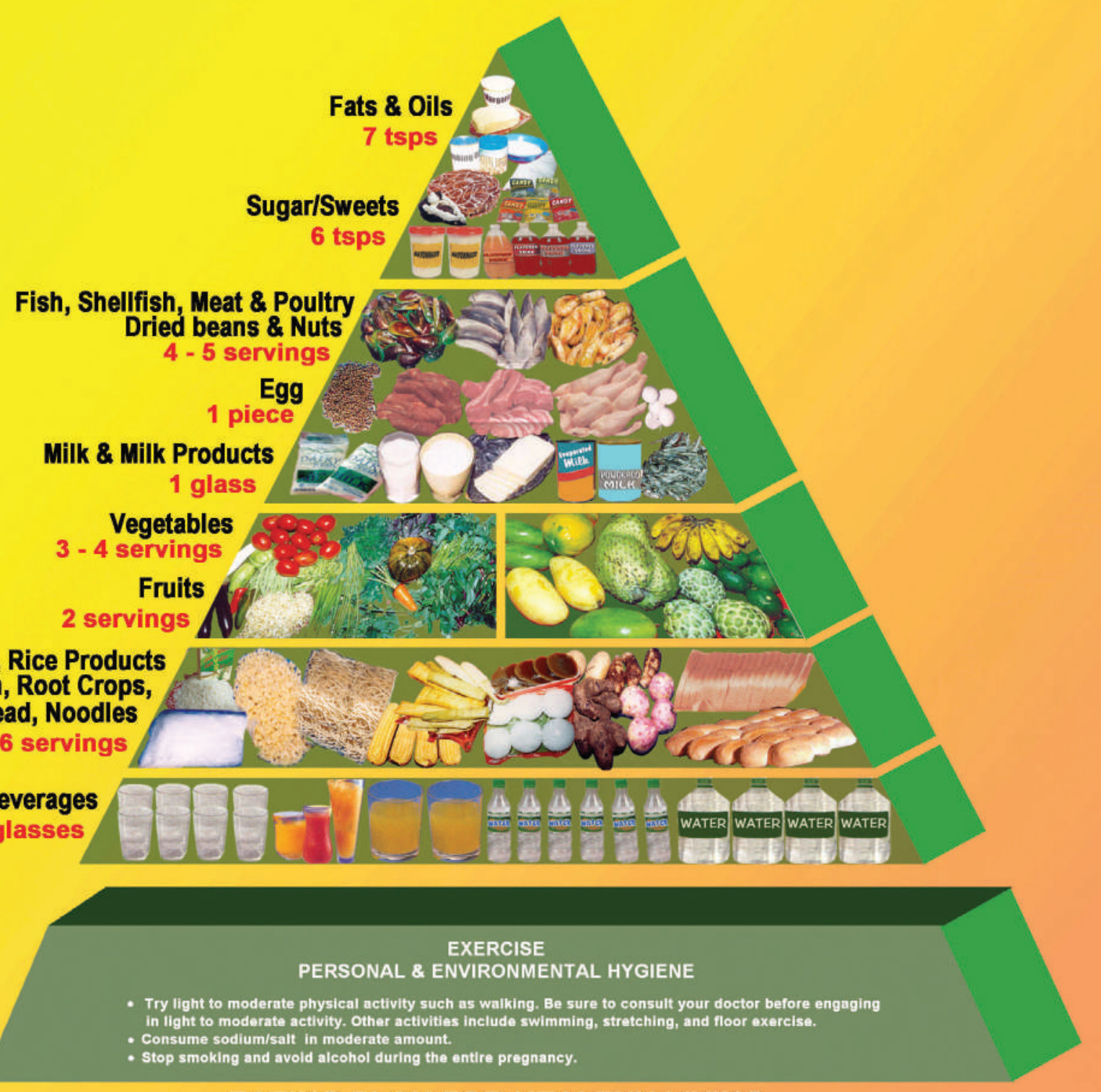

\section{EATING PLAN FOR HEALTHY LIVING}

Eat a variety of foods everyday to ensure that all nutrients are provided in proper amount and balance.

Use iodized salt and eat other fortified foods to increase the intake of micronutrients. 
Appendix B. New Recommendations for Total and Rate of Weight Gain during Pregnancy, by Prepregnancy BMI ${ }^{5}$

\begin{tabular}{|c|c|c|c|c|}
\hline \multirow[t]{2}{*}{ Prepregnancy BMI } & \multicolumn{2}{|c|}{ Total Weight Gain } & \multicolumn{2}{|c|}{ Rates of Weight Gain* 2nd and 3rd Trimester } \\
\hline & Range in $\mathbf{k g}$ & Range in lbs & Mean (range) in kg/week & Mean (range) in lbs/week \\
\hline Underweight $\left(<18.5 \mathrm{~kg} / \mathrm{m}^{2}\right)$ & $12.5-18$ & $28-40$ & $0.51(0.44-0.58)$ & $1(1-1.3)$ \\
\hline Normal weight (18.5-24.9 kg/m²) & $11.5-16$ & $25-35$ & $0.42(0.35-0.50)$ & $1(0.8-1)$ \\
\hline Overweight $(25.0-29.9$ kg/m²) & 7-11.5 & $15-25$ & $0.28(0.23-0.33)$ & $0.6(0.5-0.7)$ \\
\hline Obese $\left(\geq 30.0 \mathrm{~kg} / \mathrm{m}^{2}\right)$ & $5-9$ & $11-20$ & $0.22(0.17-0.27)$ & $0.5(0.4-0.6)$ \\
\hline
\end{tabular}

Appendix C. Food Diary (Filipino Version)

\section{Sample 24-Hour Food Recall or Food Diary Form (Pagtala ng Kinain)}

Code \#

Petsa

Listahan ng mga Kinain na Pagkain (sa loob ng 24 oras)

\begin{tabular}{|l|l|l|l|l|}
\hline \multicolumn{2}{|c|}{ Saan Kinain Pagkain } & & & \\
& & & & \\
\hline
\end{tabular}

Ito ba ang kadalasan mong kinakain? Kung hindi, bakit?

Appendix D. List of 30 food items most commonly consumed by pregnant women in descending order according to Seventh National Nutrition Survey ${ }^{3}$

1. Rice

2. Sugar

3. Cooking oil

4. Bread

5. Coffee, instant (kape, pulbos)

6. Egg, chicken, whole (itlog, manok, buo)

7. Coconut cream (niyog, kakang gata)

8. String beans (sitaw, bunga, berde)

9. Noodles, instant

10. Squash, fruit (kalabasa, bunga)

11. Banana, saba (saging, saba)

12. Horseradish leaves (malunggay, dahon)

13. Noodles, not instant

14. Milk, filled, powdered

15. Soft drinks
16. Canned sardines

17. Scad, round (galunggong)

18. Choco drink powder

19. Eggplant (talong)

20. Sweet potato, tops (kamote, talbos)

21. Crackers

22. Cabbage, green (repolyo, berde)

23. Pork, buston butt, lean (baboy, paypay, laman)

24. Mungbean, seed, green, dried (munggo buto, berde, tuyo)

25. Carrot (karot)

26. Tilapia, fresh (tilapia)

27. Indian sardine, dried (tamban, tuyo)

28. Juice, powder

29. Milk, other milk for family

30. Coffee creamer, non-dairy 
Appendix E. Food Frequency Form (Filipino Version)

\section{Sample of the Food Frequency Form ${ }^{7}$ (Tala ng Gaano Kadalas Kainin ang Pagkain)}

Code \#

Palagi bang nakakakain ng almusal? Tanghalian?

Merienda?

Hapunan?
Date

$\begin{array}{ll}\square \text { Oo } & \square \text { Hindi } \\ \square \text { Oo } & \square \text { Hindi } \\ \square \text { Oo } & \square \text { Hindi } \\ \square \text { Oo } & \square \text { Hindi }\end{array}$

Tanghalian?
Ano ang madalas na kakaligtain?

Almusal? $\quad \square$ Oo $\square$ Hindi

$\square$ Oo

$\square$ Oo

$\square$ Oo

Madalas na Kinakain

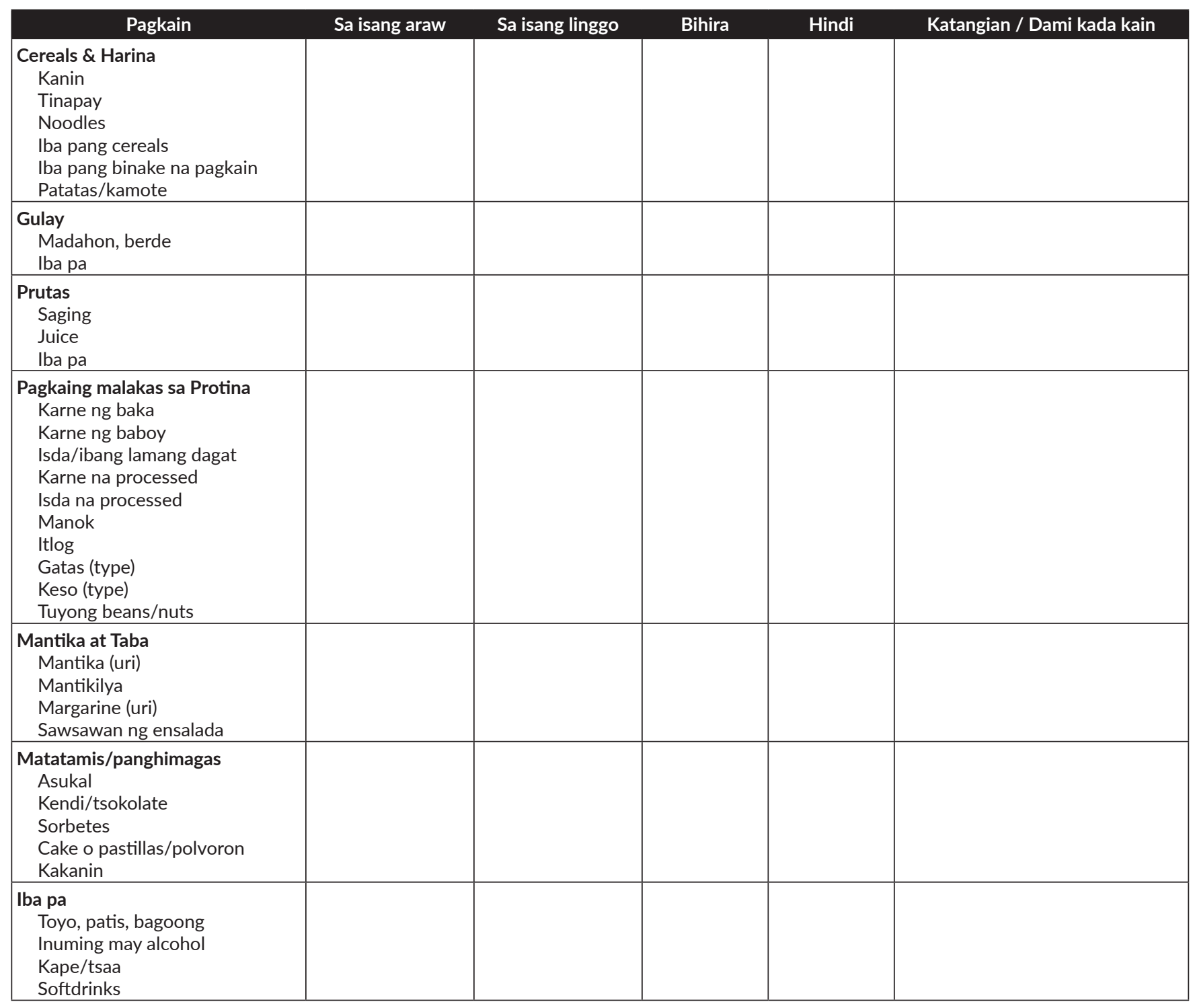

1. Iba pang pagkain na madalas kainin

2. Paboritong pagkain

3. Pagkain na di gusto

4. Allergies 
Appendix F. Recommended Energy and Nutrient Intakes for Filipinos particularly for pregnant women, taken from the Food and Nutrition Research Institute ${ }^{7}$

Recommended Energy Intakes per day

\begin{tabular}{|c|c|c|c|c|}
\hline \multirow{2}{*}{$\begin{array}{l}\text { Life stage/ } \\
\text { age group }\end{array}$} & \multicolumn{2}{|c|}{$\begin{array}{c}\text { Weight } \\
\text { (kg) }\end{array}$} & \multicolumn{2}{|c|}{$\begin{array}{c}\text { Energy } \\
\text { (kcal) }\end{array}$} \\
\hline & M & $F$ & M & $F$ \\
\hline \multicolumn{5}{|l|}{ Infants, mo } \\
\hline $0-5$ & 6.5 & 6.0 & 620 & 560 \\
\hline 6-11 & 9.0 & 8.0 & 720 & 630 \\
\hline \multicolumn{5}{|l|}{ Children, y } \\
\hline $1-2$ & 12.0 & 11.5 & 1,000 & 920 \\
\hline $3-5$ & 17.5 & 17.0 & 1,350 & 1,260 \\
\hline $6-9$ & 23.0 & 22.5 & 1,600 & 1,470 \\
\hline $10-12$ & 33.0 & 36.0 & 2,060 & 1,980 \\
\hline $13-15$ & 48.5 & 46.0 & 2,700 & 2,170 \\
\hline $16-18$ & 59.0 & 51.5 & 3,010 & 2,280 \\
\hline \multicolumn{5}{|l|}{ Adults, y } \\
\hline 19-29 & 60.5 & 52.5 & 2,530 & 1,930 \\
\hline $30-49$ & 60.5 & 52.5 & 2,420 & 1,870 \\
\hline $50-59$ & 60.5 & 52.5 & 2,420 & 1,870 \\
\hline $60-69$ & 60.5 & 52.5 & 2,140 & 1,610 \\
\hline$\geq 70$ & 60.5 & 52.5 & 1,960 & 1,540 \\
\hline Pregnant & & & & $+300^{*}$ \\
\hline Lactating & & & & +500 \\
\hline
\end{tabular}

*For $2^{\text {nd }}$ and $3^{\text {rd }}$ trimesters only
Acceptable Macronutrient Distribution Ranges

\begin{tabular}{cccc}
\hline Lifestage/ & \multicolumn{3}{c}{ Range (\% of Energy) } \\
\cline { 2 - 4 } age group & Protein & Total Fat & Carbohydrate $^{*}$ \\
\hline Infants, mo & & & \\
$\quad 0-5$ & 5 & $40-60$ & $35-55$ \\
$\quad 6-11$ & $8-15$ & $30-40$ & $45-62$ \\
Children, y & & & \\
$\quad 1-2$ & $6-15$ & $25-35$ & $50-69$ \\
$\quad 3-18$ & $6-15$ & $15-30$ & $55-79$ \\
$\begin{array}{c}\text { Adults, y } \\
\geq 19\end{array}$ & $10-15$ & $15-30$ & $55-75$ \\
\hline
\end{tabular}

NOTE: Acceptable Macronutrient Distribution Range (AMDR) is the range of intakes for a particular energy source (carbohydrate, protein or fat) that is associated with reduced risk of chronic diseases while providing adequate intakes of essential nutrients, expressed as a percentage of total energy intake.

*The AMDR for carbohydrate is the percentage of total energy available after taking into account that consumed as protein and fat, hence the wide ranges.

Recommended Nutrient Intakes per day (Macronutrients)

\begin{tabular}{|c|c|c|c|c|c|c|c|c|c|c|c|}
\hline \multirow{3}{*}{$\begin{array}{l}\text { Life stage/ } \\
\text { age group }\end{array}$} & \multirow{2}{*}{\multicolumn{2}{|c|}{$\begin{array}{l}\text { Weight } \\
\text { (kg) }\end{array}$}} & \multirow{2}{*}{\multicolumn{2}{|c|}{$\begin{array}{c}\text { Energy } \\
\text { (kcal) }\end{array}$}} & \multirow{2}{*}{\multicolumn{2}{|c|}{$\begin{array}{l}\text { Protein } \\
\text { (g) }\end{array}$}} & \multicolumn{2}{|c|}{ Essential Fatty Acids } & \multirow{3}{*}{$\begin{array}{l}\text { Dietary Fiber } \\
\text { (g) }\end{array}$} & \multirow{2}{*}{\multicolumn{2}{|c|}{$\begin{array}{l}\text { Water } \\
(\mathrm{mL})\end{array}$}} \\
\hline & & & & & & & \multirow{2}{*}{$\begin{array}{c}\alpha \text {-Linolenic Acid } \\
(\% \mathrm{E})\end{array}$} & \multirow{2}{*}{$\begin{array}{l}\text { Linoleic Acid } \\
(\% \mathrm{E})\end{array}$} & & & \\
\hline & M & $\mathbf{F}$ & M & $F$ & M & $F$ & & & & M & $F$ \\
\hline \multicolumn{12}{|l|}{ Infants, mo } \\
\hline $0-5$ & 6.5 & 6.0 & 620 & 560 & 9 & 8 & 0.5 & 4.5 & - & 680 & 680 \\
\hline $6-11$ & 9.0 & 8.0 & 720 & 630 & 17 & 15 & 0.5 & 4.5 & - & 890 & 890 \\
\hline \multicolumn{12}{|l|}{ Children, y } \\
\hline $1-2$ & 12.0 & 11.5 & 1,000 & 920 & 18 & 17 & 0.5 & 3.0 & $6-7$ & 1,000 & 920 \\
\hline $3-5$ & 17.5 & 17.0 & 1,350 & 1,260 & 22 & 21 & 0.5 & 2.0 & $8-10$ & 1,350 & 1,260 \\
\hline $6-9$ & 23.0 & 22.5 & 1,600 & 1,470 & 30 & 29 & 0.5 & 2.0 & $11-14$ & 1,600 & 1,470 \\
\hline $10-12$ & 33.0 & 36.0 & 2,060 & 1,980 & 43 & 46 & 0.5 & 2.0 & $15-17$ & 2,060 & 1,980 \\
\hline $13-15$ & 48.5 & 46.0 & 2,700 & 2,170 & 62 & 57 & 0.5 & 2.0 & $18-20$ & 2,700 & 2,170 \\
\hline $16-18$ & 59.0 & 51.5 & 3,010 & 2,280 & 72 & 61 & 0.5 & 2.0 & $21-23$ & 3,010 & 2,280 \\
\hline \multicolumn{12}{|l|}{ Adults, y } \\
\hline 19-29 & 60.5 & 52.5 & 2,530 & 1,930 & 71 & 62 & 0.5 & 2.0 & $20-25$ & 2,530 & 1,930 \\
\hline $30-49$ & 60.5 & 52.5 & 2,420 & 1,870 & 71 & 62 & 0.5 & 2.0 & $20-25$ & 2,420 & 1,870 \\
\hline $50-59$ & 60.5 & 52.5 & 2,420 & 1,870 & 71 & 62 & 0.5 & 2.0 & $20-25$ & 2,420 & 1,870 \\
\hline $60-69$ & 60.5 & 52.5 & 2,140 & 1,610 & 71 & 62 & 0.5 & 2.0 & $20-25$ & 2,140 & 1,610 \\
\hline$\geq 70$ & 60.5 & 52.5 & 1,960 & 1,540 & 71 & 62 & 0.5 & 2.0 & $20-25$ & 1,960 & 1,540 \\
\hline Pregnant & & & & $+300^{*}$ & & +25 & & & & & +300 \\
\hline Lactating & & & & +500 & & +27 & & & & & +700 \\
\hline
\end{tabular}

${ }^{*}$ For $2^{\text {nd }}$ and $3^{\text {rd }}$ trimesters only 
Appendix F. Recommended Energy and Nutrient Intakes for Filipinos particularly for pregnant women ... continued

Recommended Nutrient Intakes per day (Vitamins)

\begin{tabular}{|c|c|c|c|c|c|c|c|c|c|c|c|c|c|c|c|c|c|c|c|c|c|c|c|c|}
\hline \multirow{2}{*}{$\begin{array}{l}\text { Life stage/ } \\
\text { age group }\end{array}$} & \multicolumn{2}{|c|}{$\begin{array}{l}\text { Weight } \\
\text { (kg) }\end{array}$} & \multicolumn{2}{|c|}{$\begin{array}{c}\text { Vitamin } A^{a} \\
\text { ( } \mu \mathrm{gRE})\end{array}$} & \multicolumn{2}{|c|}{$\begin{array}{l}\text { Vitamin } D^{b} \\
(\mu g)\end{array}$} & \multicolumn{2}{|c|}{$\begin{array}{l}\text { Vitamin } E^{c} \\
\text { (mg } \alpha-T E)\end{array}$} & \multicolumn{2}{|c|}{$\begin{array}{c}\text { Vitamin K } \\
(\mu \mathrm{g})\end{array}$} & \multicolumn{2}{|c|}{$\begin{array}{l}\text { Thiamin } \\
(\mathrm{mg})\end{array}$} & \multicolumn{2}{|c|}{$\begin{array}{l}\text { Riboflavin } \\
\text { (mg) }\end{array}$} & \multicolumn{2}{|c|}{$\begin{array}{l}\text { Niacind } \\
\text { (mgNE) }\end{array}$} & \multicolumn{2}{|c|}{$\begin{array}{l}\text { Vitamin } B_{6} \\
(\mathrm{mg})\end{array}$} & \multicolumn{2}{|c|}{$\begin{array}{l}\text { Vitamin } B_{12} \\
(\mu \mathrm{g})\end{array}$} & \multicolumn{2}{|c|}{$\begin{array}{c}\text { Folate }^{e} \\
(\mu \mathrm{gDFE})\end{array}$} & \multicolumn{2}{|c|}{$\begin{array}{l}\text { Vitamin C } \\
(\mathrm{mg})\end{array}$} \\
\hline & $M$ & $\mathrm{~F}$ & M & $\mathrm{F}$ & $\mathrm{M}$ & $\mathrm{F}$ & $M$ & $F$ & M & $\mathrm{F}$ & $M$ & $\mathrm{~F}$ & M & $\mathrm{F}$ & $M$ & $F$ & $\mathrm{M}$ & $\mathrm{F}$ & M & $\mathrm{F}$ & $\mathrm{M}$ & $F$ & $M$ & $F$ \\
\hline \multicolumn{25}{|l|}{ Infants, mo } \\
\hline $0-5$ & 6.5 & 6.0 & 380 & 380 & 5 & 5 & 3 & 3 & 7 & 6 & 0.2 & 0.2 & 0.3 & 0.3 & 1 & 1 & 0.1 & 0.1 & 0.3 & 0.3 & 65 & 65 & 30 & 30 \\
\hline $6-11$ & 9.0 & 8.0 & 400 & 400 & 5 & 5 & 4 & 4 & 9 & 8 & 0.4 & 0.3 & 0.4 & 0.3 & 5 & 5 & 0.2 & 0.3 & 0.4 & 0.4 & 80 & 70 & 40 & 40 \\
\hline \multicolumn{25}{|l|}{ Children, y } \\
\hline $1-2$ & 12.0 & 11.5 & 400 & 400 & 5 & 5 & 4 & 4 & 12 & 12 & 0.5 & 0.4 & 0.5 & 0.4 & 6 & 6 & 0.5 & 0.5 & 0.9 & 1.0 & 150 & 150 & 45 & 45 \\
\hline $3-5$ & 17.5 & 17.0 & 400 & 400 & 5 & 5 & 5 & 5 & 18 & 17 & 0.5 & 0.5 & 0.6 & 0.5 & 7 & 7 & 0.6 & 0.7 & 1.1 & 1.2 & 200 & 200 & 45 & 45 \\
\hline $6-9$ & 23.0 & 22.5 & 400 & 400 & 5 & 5 & 6 & 6 & 23 & 23 & 0.7 & 0.7 & 0.7 & 0.7 & 9 & 9 & 0.7 & 0.8 & 1.3 & 1.5 & 300 & 300 & 45 & 45 \\
\hline 10-12 & 33.0 & 36.0 & 500 & 500 & 5 & 5 & 7 & 9 & 33 & 36 & 0.9 & 0.9 & 1.0 & 0.9 & 11 & 12 & 1.0 & 1.1 & 1.8 & 2.1 & 300 & 300 & 45 & 45 \\
\hline 13-15 & 48.5 & 46.0 & 700 & 500 & 5 & 5 & 10 & 9 & 49 & 46 & 1.2 & 1.0 & 1.3 & 1.0 & 15 & 13 & 1.3 & 1.2 & 2.3 & 2.2 & 400 & 400 & 60 & 55 \\
\hline $16-18$ & 59.0 & 51.5 & 800 & 600 & 5 & 5 & 11 & 10 & 59 & 52 & 1.4 & 1.1 & 1.5 & 1.1 & 18 & 14 & 1.5 & 1.3 & 2.7 & 2.4 & 400 & 400 & 70 & 60 \\
\hline \multicolumn{25}{|l|}{ Adults, y } \\
\hline $19-29$ & 60.5 & 52.5 & 700 & 600 & 5 & 5 & 10 & 10 & 61 & 53 & 1.2 & 1.1 & 1.3 & 1.1 & 16 & 14 & 1.3 & 1.3 & 2.4 & 2.4 & 400 & 400 & 70 & 60 \\
\hline $30-49$ & 60.5 & 52.5 & 700 & 600 & 5 & 5 & 10 & 10 & 61 & 53 & 1.2 & 1.1 & 1.3 & 1.1 & 16 & 14 & 1.3 & 1.3 & 2.4 & 2.4 & 400 & 400 & 70 & 60 \\
\hline 50-59 & 60.5 & 52.5 & 700 & 600 & 10 & 10 & 10 & 10 & 61 & 53 & 1.2 & 1.1 & 1.3 & 1.1 & 16 & 14 & 1.7 & 1.6 & 2.4 & 2.4 & 400 & 400 & 70 & 60 \\
\hline $60-69$ & 60.5 & 52.5 & 700 & 600 & 15 & 15 & 10 & 10 & 61 & 53 & 1.2 & 1.1 & 1.3 & 1.1 & 16 & 14 & 1.7 & 1.6 & 2.4 & 2.4 & 400 & 400 & 70 & 60 \\
\hline$\geq 70$ & 60.5 & 52.5 & 700 & 600 & 15 & 15 & 10 & 10 & 61 & 53 & 1.2 & 1.1 & 1.3 & 1.1 & 16 & 14 & 1.7 & 1.6 & 2.4 & 2.4 & 400 & 400 & 70 & 60 \\
\hline Pregnant & & & & +300 & & +0 & & +0 & & +0 & & +0.3 & & +0.7 & & +4 & & +0.6 & & +0.2 & & +200 & & +10 \\
\hline Lactating & & & & +400 & & +0 & & +4 & & +0 & & +0.2 & & +0.6 & & +3 & & +0.7 & & +0.4 & & +150 & & +35 \\
\hline
\end{tabular}

NOTE: Recommended Nutrient Intakes (RNI) are in bold font, while Adequate Intakes (Al) are in italics.

a 1 retinol equivalent $(R E)=1 \mu \mathrm{g}$ retinol $=12 \mu \mathrm{g} \beta$-carotene or $24 \mu \mathrm{g}$ other provitamin $\mathrm{A}$ carotenoids; $1 \mu \mathrm{g}$ RE $=3.33 \mathrm{IU}$ vitamin $\mathrm{A}$

${ }^{b}$ In the absence of adequate exposure to sunlight, as calciferol; $1 \mu \mathrm{g}$ calciferol $=40 \mathrm{IU}$ vitamin D

c $1 \mathrm{mg}$ alpha-tocopherol equivalent $(\alpha-\mathrm{TE})=1.49 \mathrm{IU}$ natural form or $2.22 \mathrm{IU}$ synthetic form

${ }^{\mathrm{d}}$ As niacin equivalent (NE)

e 1 dietary folate equivalent (DFE) $=1 \mu \mathrm{g}$ food folate $=0.6 \mu \mathrm{g}$ folic acid from fortified foods or as supplement $=0.5 \mu \mathrm{g}$ taken on an empty stomach

Recommended Nutrient Intakes per day (Minerals)

\begin{tabular}{|c|c|c|c|c|c|c|c|c|c|c|c|c|c|c|c|c|c|c|c|c|c|}
\hline \multirow{3}{*}{$\begin{array}{l}\text { Life stage/ } \\
\text { age group }\end{array}$} & \multirow{2}{*}{\multicolumn{2}{|c|}{$\begin{array}{l}\text { Weight } \\
\text { (kg) }\end{array}$}} & \multirow{2}{*}{\multicolumn{2}{|c|}{$\begin{array}{l}\text { Iron } \\
\text { (mg) }\end{array}$}} & \multirow{2}{*}{\multicolumn{2}{|c|}{$\begin{array}{l}\text { Zinc } \\
\text { (mg) }\end{array}$}} & \multirow{2}{*}{\multicolumn{2}{|c|}{$\begin{array}{l}\text { Selenium } \\
(\mu g)\end{array}$}} & \multirow{2}{*}{\multicolumn{2}{|c|}{$\begin{array}{c}\text { lodine } \\
(\mu \mathrm{g})\end{array}$}} & \multirow{2}{*}{\multicolumn{2}{|c|}{$\begin{array}{l}\text { Calcium } \\
\text { (mg) }\end{array}$}} & \multirow{2}{*}{\multicolumn{2}{|c|}{$\begin{array}{l}\text { Magnesium } \\
\qquad(\mathrm{mg})\end{array}$}} & \multirow{2}{*}{\multicolumn{2}{|c|}{$\begin{array}{l}\text { Phosphorus } \\
\text { (mg) }\end{array}$}} & \multirow{2}{*}{\multicolumn{2}{|c|}{$\begin{array}{l}\text { Fluoride } \\
\text { (mg) }\end{array}$}} & \multicolumn{3}{|c|}{ Electrolytes } \\
\hline & & & & & & & & & & & & & & & & & & & \multirow{2}{*}{$\begin{array}{l}\text { Sodium } \\
\text { (mg) }\end{array}$} & \multirow{2}{*}{$\begin{array}{c}\text { Chloride } \\
\text { (mg) }\end{array}$} & \multirow{2}{*}{$\begin{array}{l}\text { Potassium } \\
\text { (mg) }\end{array}$} \\
\hline & M & $\mathbf{F}$ & $M$ & $\mathbf{F}$ & $M$ & $\mathbf{F}$ & $M$ & $\mathbf{F}$ & $M$ & $\mathrm{~F}$ & $M$ & $\mathbf{F}$ & $M$ & $\mathbf{F}$ & $M$ & $\mathbf{F}$ & M & $\mathbf{F}$ & & & \\
\hline \multicolumn{22}{|l|}{ Infants, mo } \\
\hline $0-5$ & 6.5 & 6.0 & 0.4 & 0.4 & 2.0 & 2.0 & 7 & 6 & 90 & 90 & 200 & 200 & 26 & 26 & 90 & 90 & 0.01 & 0.01 & 120 & 180 & 500 \\
\hline $6-11$ & 9.0 & 8.0 & 10 & 9 & 4.2 & 3.7 & 10 & 9 & 90 & 90 & 400 & 400 & 50 & 50 & 275 & 275 & 0.5 & 0.4 & 200 & 300 & 700 \\
\hline \multicolumn{22}{|l|}{ Children, y } \\
\hline $1-2$ & 12.0 & 11.5 & 8 & 8 & 4.1 & 4.0 & 17 & 16 & 90 & 90 & 500 & 500 & 60 & 60 & 460 & 460 & 0.6 & 0.6 & 225 & 350 & 1,000 \\
\hline $3-5$ & 17.5 & 17.0 & 9 & 9 & 5.0 & 4.8 & 20 & 20 & 90 & 90 & 550 & 550 & 70 & 70 & 500 & 500 & 0.9 & 0.9 & 300 & 500 & 1,400 \\
\hline $6-9$ & 23.0 & 22.5 & 10 & 9 & 5.1 & 5.0 & 20 & 19 & 120 & 120 & 700 & 700 & 90 & 90 & 500 & 500 & 1.2 & 1.1 & 400 & 600 & 1,600 \\
\hline $10-12$ & 33.0 & 36.0 & 12 & 20 & 6.6 & 6.1 & 21 & 23 & 120 & 120 & 1,000 & 1,000 & 150 & 160 & 1,250 & 1,250 & 1.7 & 1.8 & 500 & 750 & 2,000 \\
\hline $13-15$ & 48.5 & 46.0 & 19 & (28) & 9.2 & 7.4 & 30 & 29 & 150 & 150 & 1,000 & 1,000 & 220 & 210 & 1,250 & 1,250 & 2.4 & 2.3 & 500 & 750 & 2,000 \\
\hline $16-18$ & 59.0 & 51.5 & 14 & (28) & 9.0 & 7.2 & 37 & 32 & 150 & 150 & 1,000 & 1,000 & 265 & 230 & 1,250 & 1,250 & 3.0 & 2.6 & 500 & 750 & 2,000 \\
\hline \multicolumn{22}{|l|}{ Adults, y } \\
\hline $19-29$ & 60.5 & 52.5 & 12 & (28) & 6.5 & 4.6 & 38 & 33 & 150 & 150 & 750 & 750 & 240 & 210 & 700 & 700 & 3.0 & 2.6 & 500 & 750 & 2,000 \\
\hline $30-49$ & 60.5 & 52.5 & 12 & (28) & 6.5 & 4.6 & 38 & 33 & 150 & 150 & 750 & 750 & 240 & 210 & 700 & 700 & 3.0 & 2.6 & 500 & 750 & 2,000 \\
\hline $50-59$ & 60.5 & 52.5 & 12 & 10 & 6.5 & 4.6 & 38 & 33 & 150 & 150 & 750 & 800 & 240 & 210 & 700 & 700 & 3.0 & 2.6 & 500 & 750 & 2,000 \\
\hline $60-69$ & 60.5 & 52.5 & 12 & 10 & 6.5 & 4.6 & 38 & 33 & 150 & 150 & 800 & 800 & 240 & 210 & 700 & 700 & 3.0 & 2.6 & 500 & 750 & 2,000 \\
\hline$\geq 70$ & 60.5 & 52.5 & 12 & 10 & 6.5 & 4.6 & 38 & 33 & 150 & 150 & 800 & 800 & 240 & 210 & 700 & 700 & 3.0 & 2.6 & 500 & 750 & 2,000 \\
\hline Pregnant & & & & $(+10)$ & & +5.1 & & +4 & & +100 & & +50 & & +0 & & +0 & & +0 & - & - & - \\
\hline Lactating & & & & +2 & & +6.7 & & +9 & & +100 & & +0 & & +50 & & +0 & & +0 & - & - & - \\
\hline
\end{tabular}

NOTE: Recommended Nutrient Intakes (RNI) are in bold font, while Adequate Intakes (Al) are in italics.

( ) Requirements cannot be met by usual diet alone. Intake of iron-rich and iron-fortified foods and the use of supplements are recommended, if necessary. 
Appendix F. Recommended Energy and Nutrient Intakes for Filipinos particularly for pregnant women ... continued

\section{Estimated Average Requirements per day}

\begin{tabular}{|c|c|c|c|c|c|c|c|c|c|c|c|c|c|c|c|c|c|c|c|c|c|c|c|c|c|c|c|c|c|c|}
\hline \multirow{2}{*}{$\begin{array}{l}\text { Life stage/ } \\
\text { age group }\end{array}$} & \multicolumn{2}{|c|}{$\begin{array}{l}\text { Protein } \\
\text { (g) }\end{array}$} & \multicolumn{2}{|c|}{ 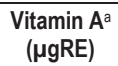 } & \multicolumn{2}{|c|}{$\begin{array}{c}\text { Thiamin } \\
\text { (mg) }\end{array}$} & \multicolumn{2}{|c|}{$\begin{array}{l}\text { Riboflavin } \\
\text { (mg) }\end{array}$} & \multicolumn{2}{|c|}{$\begin{array}{l}\text { Niacin }{ }^{b} \\
\text { (mg NE) }\end{array}$} & \multicolumn{2}{|c|}{$\begin{array}{l}\text { Vitamin } B_{6} \\
(\mathrm{mg})\end{array}$} & \multicolumn{2}{|c|}{$\begin{array}{l}\text { Vitamin } B_{12} \\
(\mu \mathrm{g})\end{array}$} & \multicolumn{2}{|c|}{ 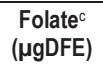 } & \multicolumn{2}{|c|}{$\begin{array}{c}\text { Vitamin C } \\
(\mathrm{mg})\end{array}$} & \multicolumn{2}{|c|}{$\begin{array}{l}\text { Iron } \\
\text { (mg) }\end{array}$} & \multicolumn{2}{|c|}{$\begin{array}{l}\text { Zinc } \\
\text { (mg) }\end{array}$} & \multicolumn{2}{|c|}{$\begin{array}{l}\text { Selenium } \\
(\mu \mathrm{g})\end{array}$} & \multicolumn{2}{|c|}{$\begin{array}{c}\text { lodine } \\
(\mu \mathrm{g})\end{array}$} & \multicolumn{2}{|c|}{$\begin{array}{l}\text { Calcium } \\
\text { (mg) }\end{array}$} & \multicolumn{2}{|c|}{$\begin{array}{l}\text { Phosphorus } \\
\text { (mg) }\end{array}$} \\
\hline & M & $\mathrm{F}$ & M & $F$ & M & $F$ & M & $F$ & M & $F$ & M & $F$ & M & $\mathbf{F}$ & M & $\mathbf{F}$ & M & $F$ & M & $\mathbf{F}$ & M & $F$ & M & $F$ & M & $F$ & M & $\mathbf{F}$ & M & $F$ \\
\hline \multicolumn{31}{|l|}{ Infants, mo } \\
\hline $0-5$ & 7 & 7 & - & - & - & - & - & - & - & - & - & - & - & - & - & - & - & - & - & - & - & - & 5.5 & 5.1 & - & - & - & - & - & - \\
\hline $6-11$ & 14 & 13 & 190 & 190 & 0.3 & 0.3 & 0.3 & 0.3 & 4 & 3 & - & - & - & - & - & - & - & - & 8.4 & 7.2 & 2.8 & 2.5 & 8.2 & 7.3 & - & - & - & - & - & - \\
\hline \multicolumn{31}{|l|}{ Children, y } \\
\hline $1-2$ & 15 & 14 & 200 & 200 & 0.4 & 0.4 & 0.4 & 0.4 & 5 & 5 & 0.4 & 0.5 & 0.8 & 0.9 & 120 & 120 & 12 & 11 & 6.4 & 7.0 & 2.8 & 2.6 & 13.6 & 13.0 & 65 & 65 & 440 & 440 & 380 & 380 \\
\hline $3-5$ & 18 & 17 & 226 & 214 & 0.5 & 0.4 & 0.5 & 0.4 & 5 & 5 & 0.5 & 0.5 & 0.9 & 1.0 & 160 & 160 & 17 & 17 & 7.5 & 7.4 & 3.3 & 3.2 & 16.1 & 15.6 & 65 & 65 & 440 & 440 & 405 & 405 \\
\hline $6-9$ & 24 & 24 & 278 & 264 & 0.6 & 0.5 & 0.6 & 0.5 & 7 & 7 & 0.6 & 0.7 & 1.1 & 1.2 & 250 & 250 & 23 & 22 & 8.6 & 7.8 & 3.4 & 3.4 & 15.6 & 15.3 & 73 & 73 & 440 & 440 & 405 & 405 \\
\hline 10-12 & 35 & 38 & 364 & 375 & 0.7 & 0.8 & 0.8 & 0.8 & 9 & 10 & 0.8 & 1.0 & 1.5 & 1.7 & 250 & 250 & 33 & 36 & 10.2 & 16.5 & 4.4 & 4.1 & 16.5 & 18.0 & 73 & 73 & 440 & 440 & 1,055 & 1,055 \\
\hline 13-15 & 50 & 46 & 483 & 392 & 1.0 & 0.8 & 1.1 & 0.8 & 12 & 10 & 1.1 & 1.0 & 1.9 & 1.8 & 330 & 330 & 48 & 45 & 18.1 & 16.5 & 6.1 & 4.9 & 24.3 & 23.0 & 95 & 95 & 440 & 440 & 1,055 & 1,055 \\
\hline $16-18$ & 59 & 49 & 563 & 427 & 1.1 & 0.9 & 1.2 & 0.9 & 14 & 11 & 1.2 & 1.1 & 2.3 & 2.0 & 330 & 330 & 58 & 51 & 12.1 & 16.2 & 6.0 & 4.8 & 29.5 & 25.8 & 95 & 95 & 440 & 440 & 1,055 & 1,055 \\
\hline \multicolumn{31}{|l|}{ Adults, y } \\
\hline 19-29 & 57 & 49 & 499 & 433 & 1.0 & 0.9 & 1.1 & 0.9 & 12 & 11 & 1.1 & 1.1 & 2.0 & 2.0 & 320 & 320 & 60 & 52 & 10.4 & 26.3 & 4.4 & 3.1 & 30.3 & 26.3 & 95 & 95 & 600 & 600 & 580 & 580 \\
\hline $30-49$ & 57 & 49 & 499 & 433 & 1.0 & 0.9 & 1.1 & 0.9 & 12 & 11 & 1.1 & 1.1 & 2.0 & 2.0 & 320 & 320 & 60 & 52 & 10.4 & 26.3 & 4.4 & 3.1 & 30.3 & 26.3 & 95 & 95 & 600 & 600 & 580 & 580 \\
\hline 50-59 & 57 & 49 & 499 & 433 & 1.0 & 0.9 & 1.1 & 0.9 & 12 & 11 & 1.4 & 1.3 & 2.0 & 2.0 & 320 & 320 & 60 & 52 & 10.4 & 8.6 & 4.4 & 3.1 & 30.3 & 26.3 & 95 & 95 & 600 & 600 & 580 & 580 \\
\hline $60-69$ & 57 & 49 & 499 & 433 & 1.0 & 0.9 & 1.1 & 0.9 & 12 & 11 & 1.4 & 1.3 & 2.0 & 2.0 & 320 & 320 & 60 & 52 & 10.4 & 8.6 & 4.4 & 3.1 & 30.3 & 26.3 & 95 & 95 & 600 & 600 & 580 & 580 \\
\hline$\geq 70$ & 57 & 49 & 499 & 433 & 1.0 & 0.9 & 1.1 & 0.9 & 12 & 11 & 1.4 & 1.3 & 2.0 & 2.0 & 320 & 320 & 60 & 52 & 10.4 & 8.6 & 4.4 & 3.1 & 30.3 & 26.3 & 95 & 95 & 600 & 600 & 580 & 580 \\
\hline Pregnant & & 71 & & - & & 1.2 & & 1.4 & & 14 & & 1.6 & & 2.2 & & 520 & & - & & 30.3 & & - & & 30.3 & & 160 & & - & & 580 \\
\hline Lactating & & 71 & & - & & 1.1 & & 1.3 & & 14 & & 1.7 & & 2.4 & & 450 & & - & & 25.0 & & - & & 35.3 & & 209 & & - & & 580 \\
\hline
\end{tabular}

a 1 retinol equivalent $(\mathrm{RE})=1 \mu \mathrm{g}$ retinol $=12 \mu \mathrm{g} \beta$-carotene or $24 \mu \mathrm{g}$ other provitamin $\mathrm{A}$ carotenoids; $1 \mu \mathrm{g}$ RE $=3.33 \mathrm{IU}$ vitamin $\mathrm{A}$

b As niacin equivalent (NE)

c 1 dietary folate equivalent (DFE) $=1 \mu \mathrm{g}$ food folate $=0.6 \mu \mathrm{g}$ folic acid from fortified foods or as supplement $=0.5 \mu \mathrm{g}$ taken on an empty stomach 